\title{
The Distribution of Passenger Pigeon on Caddo Sites in the Trans- Mississippi South
}

Timothy K. Perttula

Heritage Research Center, Stephen F. Austin State University

Laura Nightengale

Davaid H. Jurney

Follow this and additional works at: https://scholarworks.sfasu.edu/ita

Part of the American Material Culture Commons, Archaeological Anthropology Commons, Environmental Studies Commons, Other American Studies Commons, Other Arts and Humanities Commons, Other History of Art, Architecture, and Archaeology Commons, and the United States History Commons

Tell us how this article helped you.

This Article is brought to you for free and open access by the Center for Regional Heritage Research at SFA ScholarWorks. It has been accepted for inclusion in Index of Texas Archaeology: Open Access Gray Literature from the Lone Star State by an authorized editor of SFA ScholarWorks. For more information, please contact cdsscholarworks@sfasu.edu. 


\section{The Distribution of Passenger Pigeon on Caddo Sites in the Trans-Mississippi South}

\section{Creative Commons License}

\section{(c) (1) \&}

This work is licensed under a Creative Commons Attribution-NonCommercial 4.0 International License 


\title{
The Distribution of Passenger Pigeon on Caddo Sites in the Trans-Mississippi South
}

\author{
Timothy K. Perttula, Laura Nightengale, and David H. Jurney
}

\section{INTRODUCTION}

Following up on the discovery of 10 passenger pigeon elements from one bird in a Caddo burial feature (Burial 52) at the Mitchell site (41BW4) on the Red River in Bowie County, we have documented the distribution of passenger pigeon on Caddo sites in the Trans-Mississippi South. To date, we have identified 10 Caddo sites dating between ca. A.D. 1160-1710 with passenger pigeon bones, along with two Woodland period sites (generally predating ca. A.D. 800-900) in the region. These sites range as far east as the Saline River basin in Southwest Arkansas, as far west as the George C. Davis (41CE19) and Spike (41DT16) sites in East Texas, as far north as the Spiro site (34Lf40) in eastern Oklahoma, and as far south as the McLelland site (16BO236) in Northwest Louisiana, primarily situated in the Pineywoods (Figure 1). As Jackson (2005) and Jackson et al. (2012:68) have noted, the passenger pigeons found on Caddo sites appear to reflect a "southward and westward extension of their range during the Late Woodland period (ca. A.D. 700-1000) that continues into the Caddo era (ca. A.D. 1000-1500), likely reaching East Texas sometime shortly after A.D. 1000."

\section{WOODLAND AND CADDO SITES WITH PASSENGER PIGEON BONES}

Although generally rare in ancestral Caddo faunal assemblages, bones from passenger pigeons, an extinct species (Figure 2), were quite common in Late Caddo period contexts at the Hughes Mound site (3SA11) in the Ouachita River basin (Mary Beth Trubitt, December 2013 personal communication). Passenger pigeon bones are also present in both ca. A.D. 1450-1500 and A.D. 1650-1700 deposits at the Hardman site (3CL418) in the Ouachita River basin (Early 1993:147, 150). Additionally, passenger pigeon bones ( $\mathrm{n}=14$ ) have been found at the Late Caddo McCurtain phase village at the Roden site (34Mc215) along the Red River (Perino 1981). There is one passenger pigeon left humerus from Zone $\mathrm{H}$ in the platform mound at the Hatchel site (41BW3) (Darrell Creel, December 2013 personal communication; April 24, 1975 letter from Lyndon L. Hargrave on file at TARL), less than a mile north of the Mitchell site. At the Mitchell site itself, the passenger pigeon bones were found placed inside a Pease Brushed-Incised jar in Burial 52; this individual also had 100+ turtle shell fragments found beneath the left arm and hand of the deceased (a 13-17 year old individual of indeterminate sex). Bones from a single passenger pigeon have been recovered at the ca. A.D. 1650-1710 McLelland site on the Red River (Kelley 1997:103).

At the Crenshaw site (3MI6) on the Red River in southwest Arkansas, passenger pigeon bones $(\mathrm{n}=75)$ are abundant on the floor in Feature 6, the antler temple (Jackson et al. 2012:Table 3-1), and in the midden surrounding the antler temple. The antler temple deposits date at 2 sigma to between A.D. 1161-1254, calibrated (John Samuelson, December 2013 personal communication). The bones of at least 34 passenger pigeons ( $\mathrm{n}=300$ elements) have been recovered in roughly contemporaneous contexts at the George C. Davis site, in a large trash pit in one of the village areas (Thurmond and Kleinschmidt 1979:92). Passenger pigeon bones $(\mathrm{n}=2)$ were present in Burial 90 in the Great Mortuary at the Spiro site in eastern Oklahoma (Brown 1996:706), along with 10 turkey wing fan bones. This burial features dates from ca. A.D. 1350-1450, during the Spiro IV interval. Two passenger pigeon bones were recovered from Feature 3 at the Tyson site (41SY92), a large pit in a mid-14th to mid-15th century Caddo house context (Tom Middlebrook, December 2013 personal communication). 


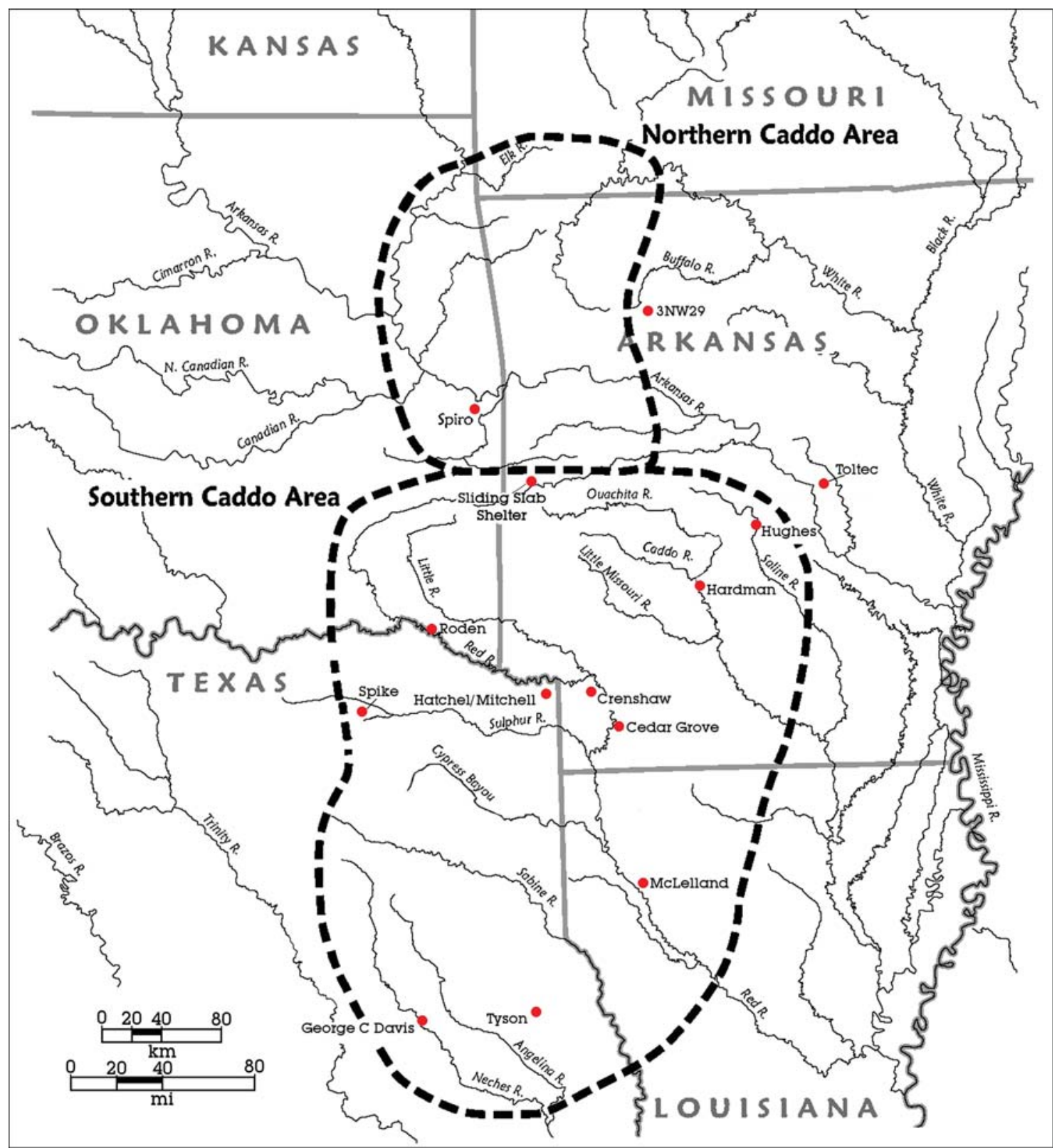

Figure 1. Sites in the Trans-Mississippi South with passenger pigeon bones.

The earliest example of passenger pigeon use in East Texas is a passenger pigeon faunal element that has been recovered in Woodland period contexts (ca. 2500-1200 years B.P.) at the Spike site (41DT16). This midden site is in the upper Sulphur River basin (Fields et al. 1993). Another passenger pigeon element has been found in a Woodland period context (ca. A.D. 800-900) at the Sliding Slab Shelter (3SB29) in the northern Ouachita Mountains in Arkansas (Harden 1981:132 and V.10).

Although not a Caddo site, passenger pigeon bones were relatively common in 8th-10th century midden deposits in Mound S at the Toltec site (3LN42) in the central Arkansas River valley (Kelly 2012:141), and other Woodland and Mississippian period sites in Northeast Arkansas, including Zebree, Knappenberger, and Ridge House and elsewhere in the state (see Jackson 2005:Table 11.1). Passenger pigeon bones are present throughout the $4 \mathrm{~m}$ of deposits at Saltpeter Cave (3NW29), in the Arkansas Ozarks. Concentrations of passenger pigeon bones are noted within Woodland period deposits at the site, which also contain at least 


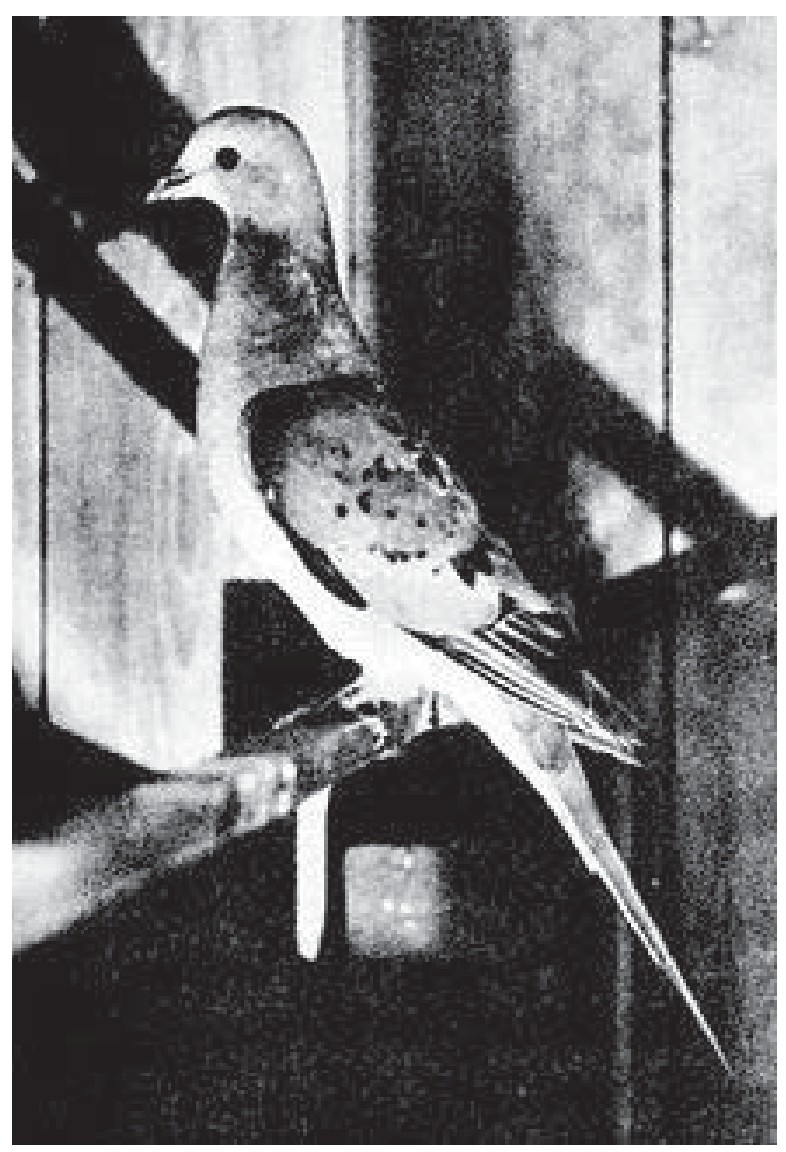

Figure 2. Early 20th century photograph of a passenger pigeon.

two burials. Passenger pigeon remains extend below the ceramic-bearing deposits into non-ceramic strata. In total, 135 elements, representing 19 minimum individuals, were recovered from Saltpeter Cave. Finally, a single passenger pigeon bone has been recovered in a refuse pit at the Poverty Point site in Northeast Louisiana (http://www.passengerpigeon.org/states/Louisiana.html), and at the famous Mississippian site of Cahokia in southern Illinois (Parmalee 1957).

According to James and Neal (1986:198), passenger pigeons did not nest in Arkansas, but they would have been locally abundant and present in roosting areas in winter months along the Red River (cf. Kelly 2012:141). There are also 19th century accounts of roosts in the Ft. Smith, Arkansas area, and several "pigeon roost" place names are known in the Ouachita Mountains.

\section{CONTEXT OF THE PASSENGER PIGEON BONES}

Passenger pigeon bones are not abundant in Late Woodland and ancestral Caddo faunal assemblages in the Trans-Mississippi South, and were not apparently an important food resource to local Caddo peoples. In most cases, the passenger pigeon bones have been found in mound contexts, in burials, probably as funerary offerings, in feasting contexts (at the Crenshaw, George C. Davis, and Tyson sites), and then lastly in habitation debris. Jackson et al. (2012:68) suggest that the passenger pigeon bones tend to occur in ritual and/or elite contexts on Caddo sites, as they do on contemporaneous Mississippian period sites in the Southeastern United States (see Jackson and Scott 1995), where they were a new and novel food item. 


\section{ACKNOWLEDGMENTS}

We thank colleagues who responded to our request for information about passenger pigeon bones: Darrell Creel, Ann M. Early, Ross C. Fields, Paul S. Gardner, Joel Greenberg, Ed Jackson, Thomas Labedz, Terrance J. Martin, Tom Middlebrook, Stephen P. Rogers, John Samuelson, and Mary Beth Trubitt. Thanks also to Lance Trask for preparing Figure 1.

\section{REFERENCES CITED}

Brown, J. A.

1996 The Spiro Ceremonial Center. The Archaeology of Arkansas Valley Caddoan Culture in Eastern Oklahoma. 2 Vols. Memoir No. 29. Museum of Anthropology, University of Michigan, Ann Arbor.

Early, A. M. (editor)

1993 Caddoan Saltmakers in the Ouachita Valley: The Hardman Site. Research Series No. 43. Arkansas Archeological Survey, Fayetteville.

Fields, R. C., E. F. Gadus, L. W. Klement, C. B. Bousman, and J. B. McLerran

1993 Excavations at the Tick, Spike, Johns Creek, and Peerless Bottoms Sites, Cooper Lake Project, Delta \& Hopkins Counties, Texas. Report of Investigations No. 91. Prewitt and Associates, Inc., Austin.

Harden, P. L.

1981 Excavations at Sliding Slab Shelter: Hunting and Gathering in the Ouachitas. Environmental Assessments, Inc., Pauls Valley.

Jackson, H. E.

2005 "Darkening the Skies in Their Flight": A Zooarchaeological Accounting of Passenger Pigeons in the Prehistoric Southeast. In Engaged Archaeology: Research Essays on North American Archaeology, Ethnobotany, and Museology, edited by M. Hegmon and B. S. Eiselt, pp. 174-199. Anthropological Papers No. 94. Museum of Anthropology, University of Michigan, Ann Arbor.

Jackson, H. E. and S. L. Scott

1995 The Faunal Record of the Southeastern Elite: The Implications of Economy, Social Relations, and Ideology. Southeastern Archaeology 14:103-119.

Jackson, H. E., S. L. Scott, and F. F. Schambach

2012 At the House of the Priest: Faunal Remains from the Crenshaw Site (3MI6), Southwest Arkansas. In The Archaeology of the Caddo, edited by T. K. Perttula and C. P. Walker, pp. 47-85. University of Nebraska Press, Lincoln.

James, D. A. and J. C. Neal

1986 Arkansas Birds: Their Distribution and Abundance. University of Arkansas Press, Fayetteville.

Kelley, D. B. (editor)

1997 Two Caddoan Farmsteads in the Red River Valley. Research Series No. 51. Arkansas Archeological Survey, Fayetteville.

Kelly, L. S.

2012 Faunal Remains from Mound S, Toltec Mounds Site. In Toltec Mounds: Archeology of the Mound-andPlaza Complex, by M. A. Rolingson, pp. 123-151. Research Series No. 65. Arkansas Archeological Survey, Fayetteville.

Parmalee, P. W.

1957 Vertebrate remains from the Cahokia site, Illinois. Transactions of the Illinois Academy of Sciences $50: 235-242$. 
Perino, G.

1981 Archeological Investigations at the Roden Site (MC-215), McCurtain County, Oklahoma. Potsherd Press No. 1. Museum of the Red River, Idabel.

Thurmond, J. P., and U. Kleinschmidt

1979 Report on the Fall 1978 Investigations at the George C. Davis Site, Caddoan Mounds State Historic Site, Cherokee County, Texas. Texas Archeological Research Laboratory, The University of Texas at Austin. 